The Common Agricultural Policy of the European Union the present and the future

Non-EU Member States point of view 



\section{INSTITUTE OF AGRICULTURAL AND FOOD ECONOMICS NATIONAL RESEARCH INSTITUTE}

\section{The Common Agricultural Policy of the European Union - the present and the future}

\section{Non-EU Member States point of view}

Editors:

dr Marek Wigier

prof. dr hab. Andrzej Kowalski

Proceedings of the International Scientific Conference

"The Common Agricultural Policy of the European Union - the present and the future" Multi-Annual Programme 2015-2019

"The Polish and the EU agricultures 2020+. Challenges, chances, threats, proposals" 5-7 December 2017 Stare Jabłonki, Poland

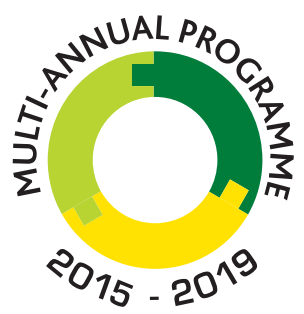

THE POLISH AND THE EU AGRICULTURES 2020+ CHALLENGES, CHANCES, THREATS, PROPOSALS

Warsaw 2018 
This monograph was prepared under the Multi-Annual Programme 2015-2019

"The Polish and the EU agricultures 2020+. Challenges, chances, threats, proposals".

The publication is a collection of selected papers delivered at the 22th edition of the International Scientific Conference organized by the Institute of Agricultural and Food Economics - National Research Institute. The theme of the conference was "The Common Agricultural Policy of the European Union the present and the future. The conference was placed on 5-7 December 2017 in Stary Jabłonki in Poland. Common Agricultural Policy was and still is one of the key pillars of European integration. Published in two volumes materials refer directly to the current and future of the CAP in EU and non EU member states, the strategic objectives and principles of agricultural policy for the agri-food sector and rural areas, address the issues of equilibrium between agriculture, forestry and land use, relate to the dilemmas for the EU budget and the CAP after 2020, CAP instruments and their adjustment, transformations of the rural economy and programming of the rural and agricultural policy, as well as productivity and production efficiency and tensions between sectoral action and between different models of territorial activities.

In the Scientific Committee of the Conference was participated: Prof. Andrzej Kowalski (IAFE-NRI, Poland), Prof. Drago Cvijanonivić (University of Kragujevac, Serbia), Prof. Thomas Doucha (IAEI, Czech Republic), Noureddin Driouech, PhD (CIHEAM, Italy), Prof. Szczepan Figiel (IAFE-NRI, Poland), Prof. Masahiko Gemma (Waseda University, Japan), Prof. Wojciech Józwiak (IAFE-NRI, Poland), Prof. Jacek Kulawik (IAFE-NRI, Poland), Prof. Yuriy Oleksiyovych Lupenko (IAE, Ukraina), Prof. Věra Majerová (CULS, Prague), Prof. Dimitre Nikolov (IAE, Bulgaria), Maire Nurmet, PhD (EMÜ, Estonia), Prof. Gabriel Popescu (ASE, Romania), Norbert Potori, PhD (AKI, Hungary), Prof. Włodzimierz Rembisz (IAFE-NRI, Poland), Piotr Szajner, PhD (IAFE-NRI, Poland), Prof. Alina Sikorska (IAFE-NRI, Poland), Prof. Jonel Subić (IAE, Serbia), Prof. Samuele Trestini (UNIPD, Italy), Prof. Olga Varchenko (Bila Tserkva National Agrarian University, Ukraine), Dipl.-Ing. Klaus Wagner (AWI, Austria), Marek Wigier, PhD (IAFE-NRI, Poland), Prof. Józef St. Zegar (IAFE-NRI, Poland)

In the Organising Committee of the Conference was participated: Małgorzata Bułkowska (IAFE-NRI, Poland), Anna Hankiewicz (IAFE-NRI, Poland), Joanna Jaroszewska (IAFE-NRI, Poland), Joanna Korczak (IAFE-NRI, Poland), Krzysztof Kossakowski (IAFE-NRI, Poland), Irena Mikiewicz (IAFE-NRI, Poland), Małgorzata Mikołajczyk (IAFE-NRI, Poland), Lech Parzuchowski (IAFE-NRI, Poland), Ewa Sierakowska (IAFE-NRI, Poland), Paulina Smakosz (IAFE-NRI, Poland), Leszek Ślipski (IAFE-NRI, Poland), Marek Wigier, PhD (IAFE-NRI, Poland).

Reviewers:

Professor Dimitre Nikolov, Institute of Agricultural Economics, Sofia, Bulgaria

Professor Gabriel Popescu, The Bucharest University of Economic Studies, Bucharest, Romania

Professor Samuele Trestini, University of Padva, Italy

Proofreader

Joanna Gozdera

Technical editors:

Joanna Jaroszewska, Barbara Pawtowska, Ewa Sierakowska, Kamila Tomaszewska,

Barbara Walkiewicz

Translated by

Summa Linguae S.A.

Cover Project

Leszek Ślipski

ISBN 978-83-7658-744-8

DOI: $10.30858 / \mathrm{pw} / 9788376587448$

Instytut Ekonomiki Rolnictwa i Gospodarki Żywnościowej

- Państwowy Instytut Badawczy

ul. Świętokrzyska 20, 00-002 Warszawa

tel.: (22) 5054444

faks: (22) 5054636

e-mail:dw@ierigz.waw.pl

http://www.ierigz.waw.pl 


\section{Contents}

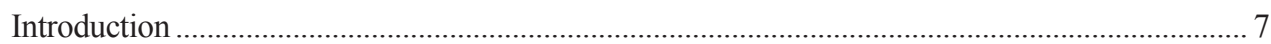

1 Urban agriculture: a framework for agricultural policy - present and future ......................... 15

Prof. Drago Cvijanović, Prof. Otilija Sedlak, Ph.D. Željko Vojinović

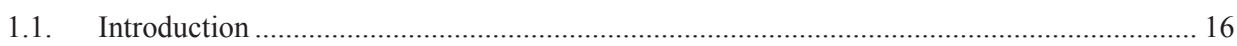

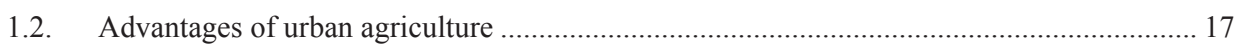

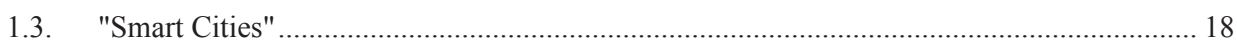

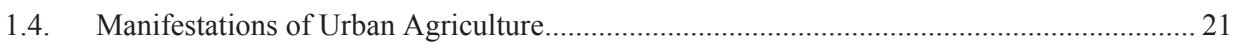

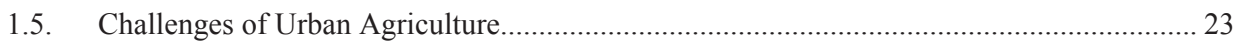

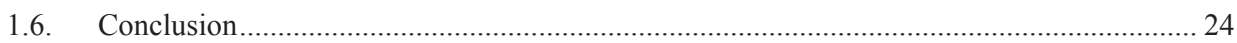

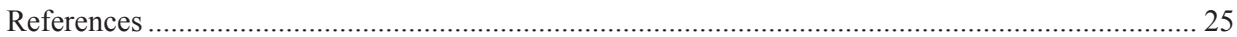

2 Land market and a village-keeping model of the agrarian system of Ukraine....................... 27

Dr Iurii Lupenko, Dr Valerii Zhuk

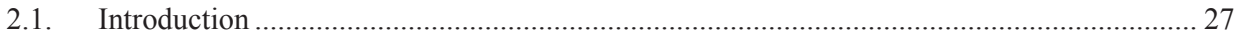

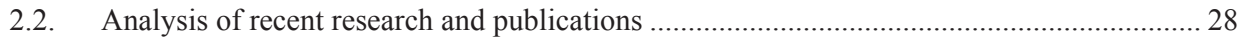

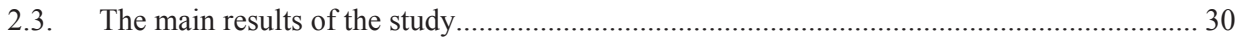

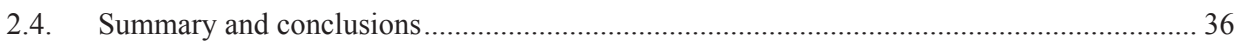

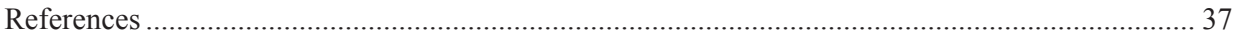

3 Agrarian policy in the European Union and financial support to Serbia................................ 38

PhD Biljana Grujić, PhD Predrag Vulović

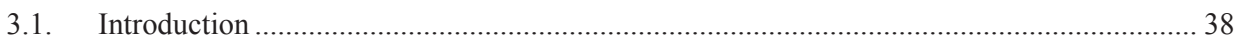

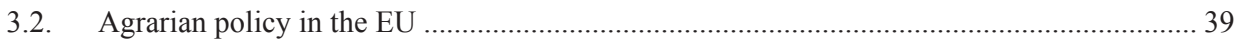

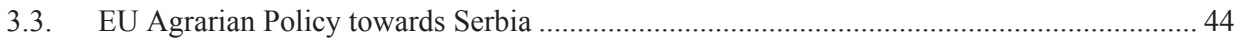

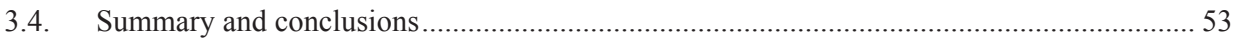

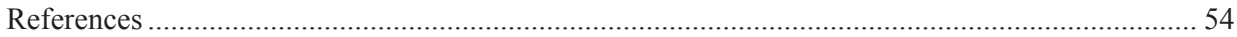

4 Ukrainian agricultural market regulation tools: their effectiveness and directions

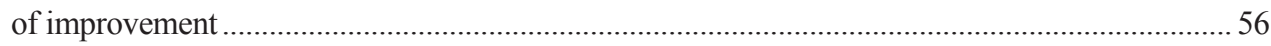

Prof. Olga Varchenko

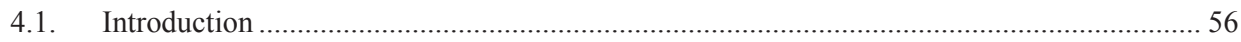

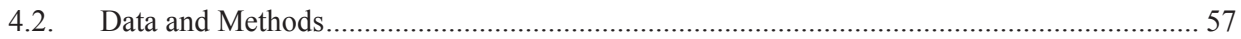

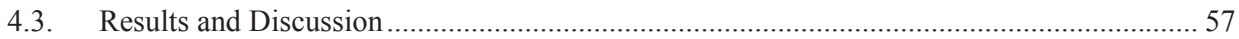

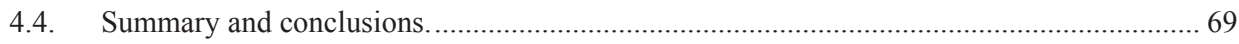

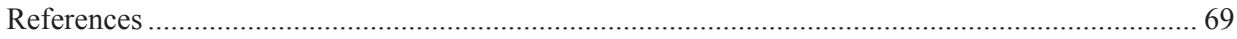


5 The Common Agricultural Policy of the European Union and the ways of its implementation in Ukraine

Dr Vasyl D. Zalizko, Prof. Nataliia M. Vdovenko, PhD Violeta L. Heraimovych, Assoc. Prof.

5.1. Introduction .71

5.2. The evolution of the EU Common agricultural policy .72

5.3. New priorities of the European Union for 2014-2020: strategic directions for Ukraine's agricultural sphere development

5.4. Organic component of the agricultural policy of Ukraine and common agricultural policy of the EU

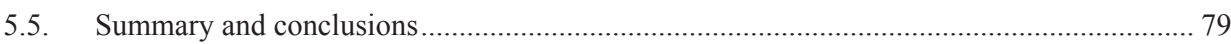

References 80

6 Farm's financing patterns and financial system development: evidence from Ukraine and Poland

Prof. Olena Oliynyk-Dunn, Prof. Viktor Adamenko

6.1. Introduction 81

6.2. Research methods 83

6.3. Results 84

6.4. Summary and conclusions 95

References .96

7 The moratorium on agricultural land sale as a limiting factor for rural development 97

Prof. Anatoliy Danylenko, PhD Tetyana Sokolska, PhD Olena Shust

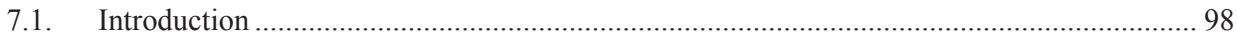

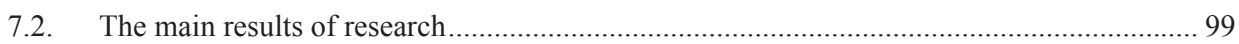

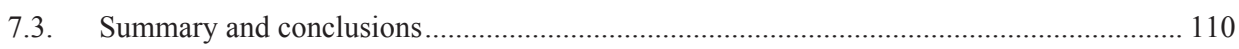

References

8 Solutions to the problems of rural territories development as a sign of their positive brand 114 Prof. Oleksandr Pavlov, Iryna Pavlova

8.1. Introduction 114

8.2. Problems of rural territories development 117

8.3. Branding as a marketing tool for solving the problems of rural territories development.... 124

8.4. Brand of rural territories development in Ukraine 127

8.5. Summary and conclusions 131

References 132

Instead of a summary 133

Annex I 


\title{
2 Land market and a village-keeping model of the agrarian system of Ukraine
}

\author{
Dr. Iurii Lupenko, Dr. Valerii Zhuk, \\ National Scientific Centre "Institute of Agrarian Economics", Kyiv, Ukraine
}

DOI: $10.30858 / \mathrm{pw} / 9788376587448.2$

\begin{abstract}
One of the problems delaying the introduction of the land market is uncertainty with the model of the agrarian system of Ukraine. Formally, the authorities favour the development of rural settlements, family farming, cooperatives, but in reality they implement an agro-holding model. In 2017, the Public Council under the Ministry of Agrarian Policy and Food of Ukraine has accepted the proposed by National Scientific Centre "Institute of Agrarian Economics" a village-keeping model of the agrarian system of Ukraine. Basis of the Model the centre of peasant and village as a guide to the content and direction of land market reform, administrative-territorial associations, budget support, taxation, rental relations, information providing of management and others.
\end{abstract}

Keywords: land market, village-keeping model, agro-holding model, rural development, agrarian system of Ukraine.

JEL codes: Q15, Q18, E65, O18, Q01

\subsection{Introduction}

The introduction of the agricultural land market in Ukraine is a topic issue for both its citizens and country lenders despite the Ukrainian authorities is still deciding which model is acceptable for this market.

An important issue nowadays is the genetic link between Ukrainian nation and agricultural land. Ukraine's political elite is aware of this, but it is extremely notable that such a link is understood also by the leadership of the European Union, the International Monetary Fund and the World Bank.

Western partners of Ukraine relate its support to the introduction of the agricultural land market, but the vision of the land market is different from those of the Ukrainian and pro-government oligarchic forces. The last ones make various draft-laws to the Parliament of Ukraine. People perceive them through the memories of the previous unpopular privatization of property. The nation does not want to repeat it with the land. Feeling the mood of Ukrainians, 
the Verkhovna Rada of Ukraine has periodically imposed a moratorium on the land market introduction since 2002.

The refusal of the government from a double position on the issues of the moratorium on the purchase and sale of agricultural land could remove political and public tensions around it. Formally, the authorities favour the development of rural settlements, family farming, cooperatives, but they pursue a policy of supporting agro-holdings, targeting land speculation in practice. That is, there are statements about one policy, model of agrarian system, and another is realized in fact.

The model of agrarian system that should be implemented after the privatization of property and land and the introduction of market conditions for management is still not officially defined in Ukraine. The authority's activity in practice is more reminiscent of the agro-holding model of agrarian system, which does not suit rural population.

It is extremely necessary for the national interests of Ukraine to adopt a public-agreed model of the agrarian system and the land market. And development of the model is the most important task for national economic science.

\subsection{Analysis of recent research and publications}

The experience of providing scientific support and implementation of the agrarian system model in Poland and other post-socialist countries is important for Ukraine. Scientists of these countries consider balanced rural development as a very important issue. In particular, in Poland and Belarus, the model and strategy of rural development have been formally approved.

The Polish model envisages active financial assistance for the modernization of farms, the restructuring of small agrarian units, the awarding of young farmers, etc. [1, 2, 11, 12]. According to the Belarusian model, a complex of measures is implemented to improve the efficiency and competitiveness of the national agro-industrial complex. And with the participation of the state it allows to solve social tasks, including the development of established agro-towns and zones of their influence - the surrounding villages. The common issue for Poland and Belarus is creating a special rural development funds (for example, the financing of projects such as "Garden green economy for rural revival (trees against poverty and land degradation)", overcoming the consequences of the Chernobyl disaster $[3,5,6,7]$.

The most comprehensive publications on the above-mentioned topics in Ukraine are the study of the famous scientist, reformer, academician Pavlo Haidutskyi. In particular, his fundamental publications "Independent Economy 
of Ukraine" [9] and "UnForgotten Reforms in Ukraine 1991-2017" [10] present the theoretical grounding, strategy and tactic of agrarian reform 1994-2005. At the same time, agrarian economists of National Scientific Centre "Institute of Agrarian Economics" Pavlo Haidutskyi, Petro Sabluk, Viktor Mesel-Veseliak, Mykola Malik, Mykola Demianenko, Oleksandr Shpychak have developed a unique scientific support for the introduction of the market model of Ukrainian agrarian system. Within it, land, tax, budget, financial and credit reforms were implemented including wide-scale privatization of property and land. The agrarian sector of the economy of Ukraine has been changed from the planned-socialist to market economy system, but in the future, it was necessary to develop and implement a new model of agrarian system based on sustainable rural development.

On response to new challenges, scientists of the National Scientific Centre "Institute of Agrarian Economics" have developed the Passport of the rural area, the mechanisms and tools for its sustainable growth. The studies of the rural communities mission in agrarian reforms conducted by Olena Borodina, Olha Popova and Ihor Prokopa are of great importance nowadays. Scientists of the Institute of Economics and Forecasting of the National Academy of Sciences of Ukraine have developed a national paradigm of sustainable development, a substantial part of which is devoted to the agrarian segment [4].

At the same time, some issues have not found proper coverage at the scientific studies. They are:

- evaluation of the destructive impact of absence a single common agricultural model of the agrarian system in Ukraine (with regional peculiarities), its place and role in agrarian reforms and politics;

- $\quad$ expediency of adding the core essence (peasant-oriented, village-oriented, etc.) to the Model's name in order to increase its understanding and acceptance by the peasants;

- definition of village-keeping functions of rural entrepreneurship at the current development;

- definition of the place and role of peasants in the functioning of the model of agrarian system.

In our previous studies, the scientific basis of the agrarian entrepreneurship and rural development under the village-keeping model was developed [8].

In the scientific report "Agricultural Land Turnover for a Village-Keeping Model of the Agrarian System" [14], the theoretical bases and practical mechanisms of the implementation of a village-keeping model of the agrarian 
system and its impact on the land market were highlighted. Some of our studies are aimed to increase the proactivity of peasants in Ukraine [13].

The purpose of the article is to reveal the main principles of the agricultural land market functioning under the village-keeping model of the agrarian system of Ukraine.

The main tasks are:

- $\quad$ to emphasize the priority of official certainty of the model of the agrarian system for the purpose of reforms and their perception by the peasantry;

- $\quad$ to reveal the main principles of the agrarian policy within agro-holding model of the agrarian system (which is unofficially implementing in Ukraine) and the village-keeping model;

- $\quad$ to prove the economic orientation of the effectiveness of a village-keeping model of the agrarian system.

\subsection{The main results of the study}

The changes that have been taking place in the agrarian sector since 2005 require new approaches for the development of the agrarian system of Ukraine. This is due to the growing tendency towards the deterioration of the structural ratio of the number of villages, their population, age and professional identity of the population. In 2018, in more than one third of rural settlements there are not any business objects at all. The tendency of monopoly on the rental market of land owned by peasants is increasing.

The solution of these problems involves the development and adoption of a new model of agrarian system.

The Ukrainian state has not yet chosen the agrarian model. Unofficial authority, consciously or unknowingly, supports the agro-holding model of rural areas. The fact that the policy and practice of agro-holding model is not declared in any government document as a model of the agrarian system of Ukraine does not really mean that it does not exist. It is de facto introducing. The peasants, in response to this, are increasing their disbelieves and aggressiveness.

Ukrainian science has developed different variants of the peasant model of the agrarian system. However, the existence of different approaches (models) for the rural development in Ukraine is a problem (Fig. 1). 
Figure 1. Modelling of the agrarian system of Ukraine: problems and ways of their solution

\begin{tabular}{|c|c|c|}
\hline Problem & Solution & Result \\
\hline $\begin{array}{l}\square \text { Absence of an } \\
\text { official of the } \\
\text { agrarian system } \\
\text { QAvailability of } \\
\text { various scientific } \\
\text { approaches (Models) } \\
\text { QUnbalanced state } \\
\text { efforts }\end{array}$ & $\begin{array}{l}\text { DExperience of } \\
\text { neighboring countries } \\
\text { oPoland } \\
\text { Belarus } \\
\text { aDiscussion and } \\
\text { adoption of the } \\
\text { desirable Model in } \\
\text { Ukraine (Public Council } \\
\text { of the Ministry of } \\
\text { Agrarian Policy and } \\
\text { Food of Ukraine) }\end{array}$ & $\begin{array}{l}\text { Dimplementation of } \\
\text { the Model by: } \\
\text { Normative legal } \\
\text { acts of the state; } \\
\text { Work of Regional } \\
\text { Innovation Centers of } \\
\text { National Academy of } \\
\text { Agrarian Science, } \\
\text { Universities and } \\
\text { Regional State } \\
\text { Administration }\end{array}$ \\
\hline
\end{tabular}

Source: Own research and generalization of authors.

The lack of a single, desirable model of rural development imbalances the efforts of all government agencies, public associations, donor projects and so on.

The Poland experience proves the enormous effectiveness of the model. It is important that focusing on the clarity, perspicuity and coherence model accepted for peasants also has significant theoretical justification.

Consequently, the absence of an officially acceptable model of the agrarian system is a destructive phenomenon both for agrarian policy and agrarian reforms. This situation is especially problematic for land reform.

From ancient times up to the present, the policy of all countries has been largely determined by an interest to land management. Science has always had a challenge of constantly seeking the ways to optimize relations related to the possession, use and disposal of land.

Ukraine has the most productive land potential in Europe. Almost 26 million hectares of agricultural land in the country have been privatized among 6.9 million peasants. By the beginning of 2017 , only about $15 \%$ of them cultivate the land itself, the rest of it is leased, or for many reasons, do not enter into land relations.

In Ukraine, for the period from 2005 to 2017, an agro-holding model of the agrarian system was being formed. 150 large companies handle about a third of agricultural land. There is a tendency towards further consolidation of business. 
The agrarian sector of Ukraine is becoming more monoculture (only cereals and oilseeds are predominant) and oriented to the export of raw materials. The employment of rural population in public agricultural production has decreased tenfold. Rural farming is declining.

The International Monetary Fund requires for abolishment of the moratorium for purchase and sale of agricultural land in Ukraine.

The big business actively struggles for the land market. According to many expert estimates, bypassing the current legislation, big business through shadow schemes bought about 3-5 million hectares of land from peasants. Ukrainians do not believe in the authorities' ability to create a land market for the national interest.

In response to these challenges, in the NSC "Institute of Agrarian Economics" has developed a village-keeping model of the agrarian system of Ukraine. The main components of this model are peasant, village and land.

A peasant is a person who owns the land and other rural assets, lives and/or has business on the rural area.

In Ukraine, the peasant is connected to the village, rarely - with an urban type village. Therefore peasant and village are related components of the Ukrainian agrarian system. The slogan of the village-keeping model "Land for Peasants" is interpreted as "Land for Villages". The agricultural land is inseparable from the village either geographically or politically and economically. Hence, the ownership of land and the peculiarities of its turnover are directly related not only to peasant-oriented, but also to village-keeping.

This vision of land use and the land market is shared by representatives of the Agrarian Union of Ukraine, the Association of Farmers and Private Landowners of Ukraine, the InterUkrainian Association of Villages and Village Councils, the Federation of Auditors, Accountants and Financiers of the agroindustrial complex of Ukraine, the Agricultural Service Cooperatives Union of Ukraine, which drives these beliefs to the paradigm level (an idea supported by the majority). Key aspects of land relations in the village-keeping model are presented in Figure 2. 
Figure 2. Agricultural land market: main aspects

1. The land is part of the National Idea. Landlessness of the peasantry will undermine national security;

2. The land for peasants. The land market is for peasants and only for peasants

3. The land is the basis of village-keeping. The land market with the participation of the community and for the village interests

\section{The effectiveness of the land market is linked to other reforms. All of them are directed for the village-keeping model of the agrarian system}

Source: Own research and generalization of authors.

However, in recent years, Ukrainian authorities have avoided a clear definition of the agrarian model of the country. There is no agreed position with society on the essence of rural entrepreneurship, rural territories, rural settlements, peasantry organization etc. In Ukraine are implemented a policy of agro-holdings.

In current discussions on the moratorium on the purchase of agricultural land abolishment, "experts" of agricultural holdings say that this will solve all the problems of the agrarian sector and allow peasants to receive funds to meet their urgent social needs.

According to the results of public statements of "experts" and the official position of the Ukrainian authorities, one can draw a certain picture of the agrarian policy by followers of the agro-holding model of the agrarian sector (Table 1). That is how the interests of big business are represented. 
Table 1. Agrarian policy by different purposes (models)

\begin{tabular}{|c|c|c|}
\hline Object of & "Village-keeping" & "Agroholding model" \\
\hline - Iand market: & For peasints & For citizens of I 'kraine \\
\hline $\begin{array}{l}\text { Land market under } \\
\text { control of: }\end{array}$ & $\begin{array}{l}\text { P'ublic-state institutions } \\
\text { Rural community }\end{array}$ & State Geocadaster of T kraine \\
\hline - Transfer to land lease: & Corporate' & Individual \\
\hline $\begin{array}{l}\text { Association of } \\
\text { inhahitants hy: }\end{array}$ & $\begin{array}{c}\text { Villages } \\
\text { Rural communities }\end{array}$ & $\begin{array}{l}\text { Territorial (united) } \\
\text { communitios }\end{array}$ \\
\hline $\begin{array}{l}\text { Rural assets / } \\
\text { Crovernment: }\end{array}$ & For villages & $\begin{array}{l}\text { For territorial (united) } \\
\text { communities }\end{array}$ \\
\hline - Preferential taxation: & $\begin{array}{l}\text { For village-kecping } \\
\text { entrepreneurship }\end{array}$ & $\begin{array}{c}\text { Fol all the agricultural } \\
\text { enterprises }\end{array}$ \\
\hline
\end{tabular}

Source: Own research and generalization of authors.

The position of the village-keeping model is peasant- and village-oriented. Land relations in this model are based on agrarian reforms of the previous model of the agrarian system, which transformed the rural sector into market relations, had a social orientation of land reform.

It is important to refute the main argument of the supporters of the agroholding model as for the imbalance of the land market under village-keeping model. They say there will be no land market in Ukraine after the implementation of the village-keeping model. Our calculations show the opposite.

According to sociological surveys conducted by the Centre of Social Expertise of the Institute of Sociology of Ukraine, today the share of land plot owners willing to sell them is from 6 to $15 \%$. It is important that $6 \%$ of the owners are ready to sell plot at a price of about 20-30 thousand UAH per hectare (that is equal to 1 thousand USD). For the rest owners the acceptable price is 50-70 thousand UAH per hectare (about 2 thousand USD). Thus, 4.1 million hectares of land worth about 105-240 billion UAH (3-8 billion USD) may be included in the market turnover. We assume (Figure 3) that the first $6 \%$ of the land owners are the most in need and do not expect an increase in the market price of 1 hectare of land. Perhaps some of them have already "sold" their units 
through agreements of perpetual lease. So, it is about 0.8-1.3 million hectares of land worth up to 1.3 billion USD.

Figure 3. Expected balance of the land market under the village-keeping model of the agrarian system

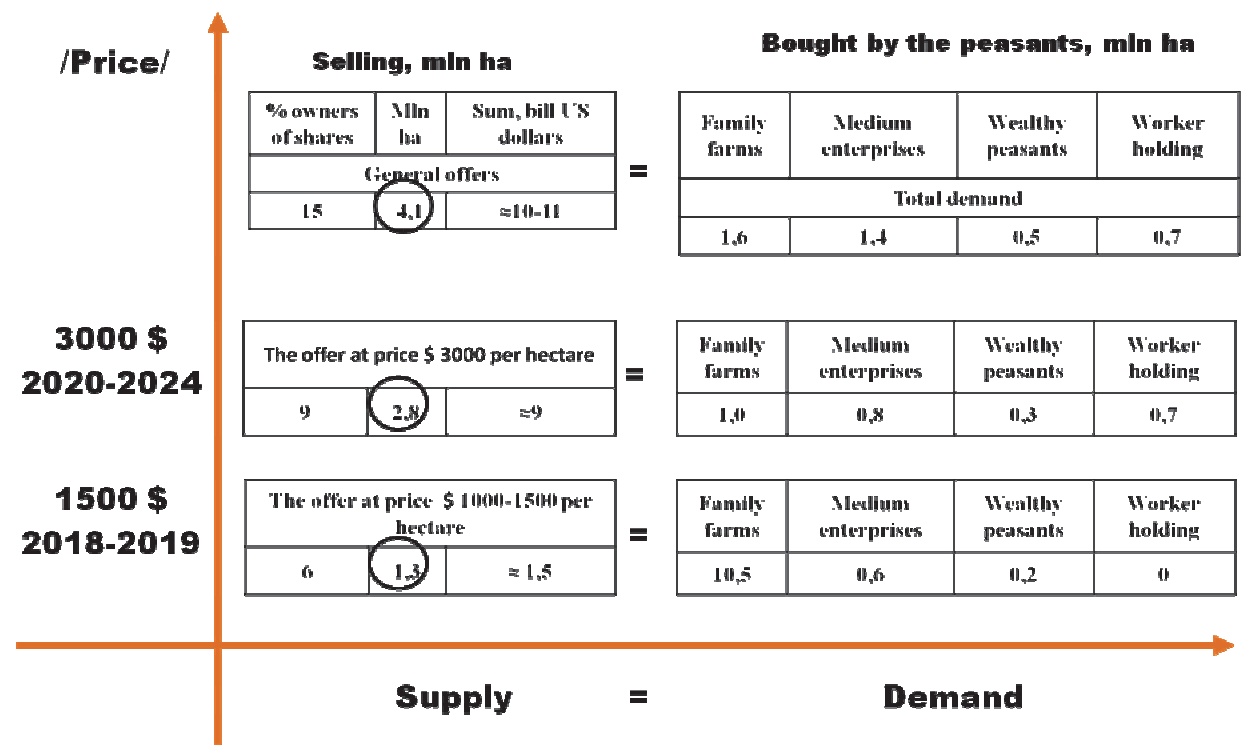

Source: calculated according to the data from the Center for Social Expertise of the Institute of Sociology of Ukraine and the NSC "Institute of Agrarian Economics".

Such a proposal will find demand among Ukrainian peasants. The farmers will be able to redeem about 300 thousand hectares of land and owners of small and medium enterprises - about 700 thousand hectares (averagely less than 10 hectares per one farmer and about 50 hectares per one owner of a medium enterprise). The rest of the land - about 300 thousand hectares - would be bought out by the peasants who now manage their own units (which, in addition, will receive budget support for such purposes in the case of the family farm registration according to village-keeping model).

It is assumed that in the first stage, the demand will exceed the supply, and the market price of 1 hectare of land will amount to more than 1500 USD. But the above balancing as a whole will not change.

At the next stage (1-2 years after the introduction of the village-keeping model and the peasant-oriented land market), it is expected that those $9 \%$ of the peasants who would sell the land at a price of 2 thousand US dollars will be offering it at a price of about 3 thousand USD per hectare. Will the demand be balanced by peasants' proposal? Yes, hopefully. 
The common offer on the second stage (Figure 3) will amount to about 2.8 million hectares of land. Based on a price of 3000 USD per hectare, this value will be approximately 9 billion USD.

We expect in 5-7 years after the introduction of the land market the combined budget support for direct purchase of land by family farms will amount to about 1 billion USD.

In addition, the State Land Bank and the Program of Compensation of Credit Rates for peasants for the purchase of land will start working. The village-keeping model predicts increasing in profitability by about 2 times of peasants' business activation, which will satisfy the demand by roughly 3 billion USD. All this, together with the Credit compensation program for land purchase from the State Land Bank (about 0.5 billion USD), will aggregate demand at 6-7 billion USD.

Covering the remaining supply at the level of 2-3 billion USD it is expecting from the investments of agro-holdings to buy land by their workers, which are peasants. According to our model, re-registration of agro-holdings units in villages is foreseen. Approximately 19 thousand of such legal entities have the potential to redeem in average of 200 hectares of land on their employees, which is potentially 4 million hectares in the whole country in the amount of 12 billion USD. In our calculation we consider only 0.7 million hectares of land worth 2-3 billion USD.

Thus, the turnover of agricultural lands under the village-keeping model is fully balanced. As a result, Ukraine, like the entire civilized world, has the opportunity to introduce an agricultural land market exclusively among peasants and for rural development.

\subsection{Summary and conclusions}

The calculations confirm the following postulates:

- $\quad$ the village-keeping model of the agrarian system of Ukraine outlines and aims to introduction of agricultural land market for peasants;

- $\quad$ land market as an instrument is extremely necessary for its redistribution from passive peasants to more active landowners;

- $\quad$ agricultural land belongs to the peasants and not to all Ukrainian citizens;

- $\quad$ exclusively among peasants land market is profitable for Ukraine in the short and long term;

- introduction of the land market under village-keeping model of the agrarian system removes public and political tensions in Ukraine around the moratorium on the purchase and sale of agricultural land. 


\section{References}

1. Adamowicz M., Smarzewska A. (2009). Model oraz mierniki trwałego i zrównoważonego rozwoju obszarów wiejskich w ujęciu lokalnym. Zeszyty Naukowe Szkoły Głównej Gospodarstwa Wiejskiego w Warszawie. Polityki Europejskie, Finanse i Marketing, 1 (50), pp. 251-268.

2. Apostel L. (1960). Towards the Formal Study of Models in the Non-Formal Sciences, Synthese, 12, pp. 125-161.

3. Bański J., Czapiewski K. (2009). Analiza zróżnicowania i perspektyw rozwoju obszarów wiejskich w Polsce do 2015 roku. Studia Obszarów Wiejskich, Warszawa, 16, PTG, IGiPZ PAN.

4. Borodina O.M., Popova, O.L., Prokopa, I.V. (Eds.) (2015). Community-based rural development policy: a scientific report. Kyiv: Institute of Economics and Forecasting, National Academy of Sciences of Ukraine.

5. Brol R. (2006). Rozwój regionalny, jako kategoria ekonomiczna, D. Strahl (Ed.), Metody oceny rozwoju regionalnego, Wyd. Akademii Ekonomicznej, Wrocław, pp. 22-38.

6. Churski P. (2009). Obszary problemowe w gospodarce przestrzennej i planowaniu przestrzennym - doświadczenia krajowe i międzynarodowe, Ministerstwo Rozwoju Regionalnego. Warszawa. Available at: http://www.mrr.gov.pl/aktualnosci/polityka_rozwoju/CHURSKI.pdf.

7. Domański R. (2009). Gospodarka przestrzenna, Podstawy teoretyczne. PWN, Warszawa.

8. Gadzalo Y.M., Zhuk V.M. (2015). Scientific basis of agrarian entrepreneurship and rural development under a rural-keeping model (scientific report). Kyiv, NSC "Institute of Agrarian Economics".

9. Haidutskyi P.I. (2014). InDepended economics of Ukraine. - Kyiv, Information systems.

10. Haidutskyi P. (2017). UnForgotten reforms in Ukraine. - Kyiv: DKS-center,

11. Program Rozwoju Obszarów Wiejskich na lata 2014-2020 (2014). Ministerstwo Rolnictwa i Rozwoju Wsi, Warszawa, Available at: http://www.minrol.gov.pl/Wsparcie-rolnictwa/Program-Rozwoju-ObszarowWiejskich-2014-2020.

12. Thöle A. J. (2013). Modele rozwoju obszarów wiejskich w ujęciu teoretycznym. Regional dimension of changes in Polish rural areas - spatial and economic aspects, Rural Studies, 34. Available at: http://www.rcin.org.pl/igipz/Content/46291/WA51_62902_r2013t34_SOW.pdf

13. Zhuk V.M. (2017). Informal institutions of the peasantry in the modeling of reforms and agrarian policy: theory and practice. Economy of agrarian and industrial complex, 9, pp. 5-19.

14. Zhuk V.M. (2017). The circulation of agricultural land in the village-keeping model of the agrarian system of Ukraine: a scientific report. Kyiv, NSC "Institute of Agrarian Economics". 